\title{
Vocabulary Learning on Junior High School Students' Textbook
}

\author{
Kisyani \\ Universitas Negeri Surabaya \\ Surabaya, Indonesia \\ kisyani@unesa.ac.id \\ Maria Mintowati \\ Universitas Negeri Surabaya \\ Surabaya, Indonesia \\ mintowati@unesa.ac.id
}

\author{
Mukhzamilah \\ Universitas Negeri Surabaya \\ Surabaya, Indonesia \\ mukhzamilah@unesa.ac.id \\ Fafi Inayatillah \\ Universitas Negeri Surabaya \\ Surabaya, Indonesia \\ fafiinayatillah@unesa.ac.id
}

\begin{abstract}
Indonesian language vocabulary has improved. This case is testified by the increasing number of word entries in Indonesian Big Dictionary or the so-called Kamus-Besar-BahasaIndonesia (KBBI): 62,100 entries (edition I, 1998); 72,000 (edition II, 1991); 78,000 (edition III, 2005); 90,000 (IV edition, 2008), 127.036 (edition $V, 2016$ ). While the number of the words of Indonesian language is developing, the curriculum in its education level is changed. In 1994 curriculum, it was mentioned that elementary school graduates should have mastered 9,000 vocabularies; 15,000 for junior high schools; and 18,000 for high schools. However, in the competency-based curriculum, the later one, it is changed into $\mathbf{1 2 . 0 0 0}$ vocabularies for High School graduates. Unfortunately, there is no limit of the vocabulary mastery in the 2013 curriculum, the latest. So far, the standard of vocabulary measurement of the vocabulary that needed to be achieved on the students' textbook have not yet existed. In connection with this, a research is done for calculating entries in the Indonesian language. There are some difficulties in vocabulary counting because there are some unique words. Apart from that, coupled with the help of the manual, the calculation of the entries in the Indonesian language textbook of SMP shows the results in the range of 4,000 entries. Compared to the equivalent class in America with 86,741 entries and compared with the number of entries in the current KBBI totalling 127,036 , the number of entry for junior high school students still appears to be lacking.
\end{abstract}

\section{Keywords—vocabulary, junior high school, students}

\section{INTRODUCTION}

Currently, the results of several international tests have shown that students' literacy level in Indonesia is still far from being satisfactory. The 2011 PIRLS or Progress of International Reading Literacy Study (PIRLS) which evaluated the reading literacy of fourth graders indicated that Indonesia ranked 42nd of 45 participating countries. In a similar vein, the 2015 PISA, or Program for International Student Assessment that evaluated the ability of 15-year-old students in reading, math, and science placed Indonesia at rank 64th of 70 countries. The result of INAP or Indonesian National Assessment Program that evaluates students' abilities in reading, math, and science is also parallel to PIRLS ( $46.83 \%$ of students scored below standard in reading competence). This literacy test is conducted by measuring the aspects of understanding, using, and reflecting the reading result in a written form containing vocabulary. Writing, in this case, a student book containing vocabulary is one of the essential things that support the development of students' literacy. This study used textbook of Indonesian students of Junior High School level (class VII, VIII, IX). The development of vocabulary contained in the students' textbook become essential to be analysed. This study also discussed the development of favourite's entry and growth of affix included in student books, including prefixes, infixes, and suffixes.

Research on reading vocabulary (RV) involves linguistics and education as a part of knowledge branch. For this reason, this study is a convergence of science field between linguistic and education. Jacobson, Harris [1] lists vocabularies based on computer analysis of all the words in six series of elementary and six reading textbooks for grades 1-6. The result list consists of a "Main List", a word that appears three or more times, and a list of 1,699 words added. There is also a "Glossary" for the four subject areas and an entire list alphabetically. In his research, the inflexion form is presented according to the roots.

Another study related to vocabulary development has been conducted by Mixan [2]. She underlined that one of crucial aspects of literacy is vocabulary development. In her experiment, she promoted several methods in enhancing level of speech for classroom activity.

Carrol, Devies, and Richman [3] compiled an "American Treasure List" based on 1,045 samples of various class 3-9 reading materials. The list contains 86,741 entries including each unique item that the computer has identified as a different word from the word that precedes and follows it. A total of 35,000 words turned out to appear only once in the reading. The list is arranged alphabetically and by the frequency of occurrences.

Furthermore, as a comparison, there is also a standard of vocabulary mastery in China, the so-called HSK (hanyushuipingkaoshi, 汉语水平考试) which is a standard Chinese mastery test for foreign and minority speakers in China. This test is equivalent to TOEFL for foreign learners of English. HSK's organizer is the People's Republic of China, through Hanban (国 i- 国). HSK consists of 2 rankings namely HSK beginner level and advanced level. The beginner level HSK 
consists of HSK 1, 2, 3, while the advanced HSK consists of HSK 4, 5, and 6. What is interesting is that these levels describe the number of words and characters (hanzi) as well as the test material at that level. HSK level 1 tests the mastery of 150 words / 178 characters; HSK 2 (300 words / 349 characters; HSK 3 (600 words / 623 characters); HSK 4 (1200 words / 1071 characters); HSK 5 (2500 words / 1709 characters); HSK 6 (5000 words / 2633 characters). HSK test materials, words and characters also underlie the development of teaching materials in various textbooks, both for Mandarin subjects / linguistics (reading, writing, and grammar comprehension) for foreign speakers and ethnic minorities in China, while the ability to speak is tested through HSKK (Hanyushuipingkaoshikouyu; 汉语水平考试口

语). From the description above, it is concluded that the number of entries lema (letters) has been standardized, both as a basis for the development of teaching materials and as determinants of Chinese mastery for test foreign and ethnic minorities in China.

Those comparisons indicate that there should be a study at the same framework in measuring the number of standardized vocabulary that need to be achieved by the students in Junior High School, as done by this research. Hence, August [4] acknowledged that the students' vocabulary development are needed to comprehend a text. Being able to measure the vocabulary development of Junior High School students as stated in their textbook is highly required to be conducted.

\section{Reading Vocabulary (RV) and Writing Vocabulary (WV)}

Vocabulary is the word possessed by a person or a language [5]. In general, the vocabulary is interpreted by a set of words owned by someone who speaks. The mastery can be active or passive. The skill of the language productively used to communicate requires active vocabulary mastery. The passive ability is related to knowledge for understanding, not for use. In this case, VR is a passive vocabulary.

The word occupies an essential position in the language system. Therefore, the mastery of one's vocabulary is crucial to success in communicating. Vocabulary learning aims to enrich the vocabulary of students. Students do not have to memorise some words, but the important thing is to use them in sentences. Knowing and understanding the meaning of words is the primary purpose of learning vocabulary.

Lado [6] argues that a person is said to have mastered the vocabulary of a language if he has learned some words that are media have the necessary knowledge and know the intricacies of vocabulary hearings, speech vocabulary, VR, and VW. According to him, the vocabulary of the second language can be divided into three levels: easy, medium, and challenging to learn Easy-to-learn lexicon is a vocabulary of the same form and meaning as L1 (language 1); a vocabulary that is encompassing contextual words: food, clothing, sports, town, village, discovery, geography, newspapers, education, etc. The probe vocabulary is a different vocabulary with $\mathrm{L} 1$, both form and meaning.

American researcher [7] in the vocabulary of urban children shows that three quarters have had about 1500 words in the first half of the first year of class 1. According to Dale [7], words dominated by first graders are words expressing taste, everyday vocabulary, words that appear almost in every sentence, and words that call the things that have been experienced and lived child. According to Dale's [7] research, the children ended class 1 with a vocabulary of 3,000 words, adding a yearly vocabulary of around 1,000 words. The average vocabulary for 12th graders is around 14000 and for students around 18000-29000 words [1]

The development of language is very fast lately positively affects the mastery of vocabulary students. Therefore, research on vocabulary should be done periodically. Sarwadi's et al. [8] study of the vocabulary of elementary and Junior High School students in Central Java and Yogyakarta shows that vocabulary mastery of grade 6 students is 4000 words. Also, there is also a word whose frequency of occurrence is high based on the case result of essay writing responded to the theme which has been determined. Edgar Dale's [7] research on the vocabulary of city children has resulted in three-quarters of the city's children having about 1,500 words in the first half of the year (1st grade). Words are known to grade 1 children: (1) a word expressing taste; (2) the vocabulary used daily; (3) words that appear in almost every sentence; and (4) words that mention what the child has experienced and experienced (cf. en wikipedia.org/wiki/edgar dale).

Harris Jacobson [1] lists vocabularies based on computer analysis of all the words in six series of elementary and six reading textbooks for grades 1-6. This list consists of a list of the main words that appear three or more times in the reading by class; An additional list of 1,699 words compiled by class; Glossary in four fields of study; The whole list is alphabetical; The form of inflexion is presented according to its roots. The American study of reading is based on 1,045 samples taken from various readings for grades 3-9. The list contains 86,741 entries including each item that the computer has identified as a different word from the word that preceded or followed it, including words, formulas, and so on. A total of 35,000 words appear only once in the reading. In Indonesia, based on the 1994 curriculum, junior high school graduates are expected to have 15,000 vocabularies, and 21,000 vocational high school graduates [9]. In the competency-based curriculum [10], high school students are only required to master 12,000 vocabularies (down compared to the previous curriculum). Then, another study focused on Student Reader vocabulary found that the number of vocabulary used in the sixth grade is smaller $(3,244$ words) than the fifth class $(3,727)$ and smaller also of class IV (3.253). Research conducted by Supriadi [10] suggests that a large number of high school package books is the very low level of legibility. One of the indications is foreign vocabulary for students [11].

Furthermore, it is believed that the development of sentences and VR in the textbook will affect the mastery of learners of the concepts and meaning of the vocabulary that is in textbooks or textbooks. The vocabulary in the textbook evolves according to the development of science and technology. This is the approach used in the Curriculum 2013, the scientific approach. With this approach, the vocabulary automatically used in textbooks also refers to the development of vocabulary as a science advocate. Thus, students are expected to have the knowledge and mastery of the vocabulary used in the textbook to the fullest. This relates to the vocabulary used to be strictly by the current Curriculum 2013. Know and understand the meaning of the word is the basic 
foundation of students to master a field. It's just that first learning on the introduction or socialization of vocabulary seems less well cared for right now. If reading is a receptive activity, then writing is a productive activity. Therefore, the mastery of vocabulary in writing activities is an active mastery relating to mastery for use. In this case, VW is an active vocabulary.

\section{METHOD}

This descriptive quantitative research uses the application to analyse the data in addition to manual analysis. As for analysing the development of VR planning techniques used to compare and differentiate [12]. Making the application of the entry is made with the following stages.

\section{A. Procedures of Data Collection}

The procedure of collecting the data in this study have been divided into three steps, namely providing files and printing of Indonesian language textbooks in Junior High School based on Curriculum 2013, retrieving language data from the student's books (drawings and columns omitted), and the last is retrieving student writing data by asking students to write.

\section{B. Tabulation and Data Analysis}

The data analysis has been done in such way by grouping data based on class level; and uploading the pdf file data in the entry computer application. After putting the data in the software application, the result report shows alphabetic list of vocabulary, the frequency of occurrence of VR and vocabulary list based on the order of usage frequency (from highest to lowest by keeping in mind the alphabetical order for the same number of occurrences, and the occurrence of occurrence frequency. The next step is calculating the increase in the number of vocabularies for each grade improvement and interpretation.

Vocabulary Identification Read The number of words used in the Junior High School Student Book is counted with the entry application. This descriptive quantitative research uses the application to analyse the data in addition to manual analysis for analysing the development of VR planning techniques used to compare and differentiate [11]. Making the application of the entry is made with the following stages. Procedures of Data Supply a) providing files and printing of Indonesian language textbooks in junior high school based on Curriculum 2013 b) retrieving language data from the student's books (drawings and columns omitted) c) retrieving student writing data by asking students to write Tabulation and Data Analysis a) Grouping data based on class level; b) Upload pdf data in the entry application; c) Downloading the results (the results report of the entry application) showing: (1) alphabetic list of vocabulary; (2) the frequency of occurrence of VR and vocabulary list based on the order of usage frequency (from highest to lowest by keeping in mind the alphabetical order for the same number of occurrences, (3) the occurrence of occurrence frequency d) Calculating the increase in the number of vocabularies for each grade improvement, , and interpret it; e) Prepare a list of VR s from foreign / regional languages (done manual).

\section{RESULT AND DISCUSSION}

Based on the analysis done, the results achieved are as follows.

\section{A. Reading Vocabulary}

Reading vocabulary identification is counted with the entry application. Here are a development table word and entry contained in junior high school books.

TABLE 1. IDENTIFICATION OF VR DEVELOPMENT

\begin{tabular}{|l|l|l|l|l|l|}
\hline $\begin{array}{l}\text { DESCRIP } \\
\text { TION }\end{array}$ & $\begin{array}{l}\text { GRADE } \\
\text { VII }\end{array}$ & $\begin{array}{l}\text { Decrea } \\
\text { se }(\%)\end{array}$ & $\begin{array}{l}\text { GRADE } \\
\text { VIII }\end{array}$ & $\begin{array}{l}\text { Decrease } \\
(\%)\end{array}$ & $\begin{array}{l}\text { GRADE } \\
\text { IX }\end{array}$ \\
\hline $\begin{array}{l}\text { Number } \\
\text { of words }\end{array}$ & 50.080 & $\begin{array}{l}-1969 \\
(3,9 \%)\end{array}$ & 48.111 & $\begin{array}{l}-9.064 \\
(18,8 \%)\end{array}$ & 39.047 \\
\hline $\begin{array}{c}\text { Num } \\
\text { ber of } \\
\text { entries }\end{array}$ & 5.045 & $\begin{array}{r}15 \\
6(3 \%)\end{array}$ & 4.889 & $\begin{array}{l}-1769 \\
(36 \%)\end{array}$ & 3.120 \\
\hline
\end{tabular}

The table 1 shows that the number of words and entries has decreased. The entry from class VII to class VIII fell by $3 \%$. As for from grade VIII to class IX down 36\%). The decrease of entry from class VIII to class IX is almost twice the percentage compared with decreasing word count. (30\%). The following table shows the results of this study compared with previous studies of the similar form of VR comparisons for various levels.

As for from grade VIII to class IX down 36\%). The decrease of entry from class VIII to class IX is almost twice the percentage compared with decreasing word count. (30\%). The following table shows the results of this study compared with previous studies of the similar form of VR comparisons for various levels.

TABLE 2. COMPARISON OF VR PLANNING FOR VARIOUS LEVELS OF AMERICAN CLASS

\begin{tabular}{|c|c|c|c|c|}
\hline CLASS & Amerika & Zuhdi & Sarwadi & Result \\
\hline 1 & & & & \\
3 & 3000 & & \\
4 & & & & \\
5 & & 3.253 & & \\
6 & & 3.727 & & \\
7 & & 3.244 & 4000 & 5.045 \\
8 & & & & 4.889 \\
9 & 86.741 & & & 3.120 \\
\end{tabular}

Based on the table 2, it appears that the development of the entry in SMP is not proper because it decreases. Especially when compared with the entries developed in books in America (86.741). With the highest number of 5,045, it means students are only introduced by exposing about $5.8 \%$ of them or less than $6 \%$. Compared to the 127,036 Indonesian entries in Bahasa Indonesia (KBBI edition V), only about $4 \%$ of the entries were 
introduced to junior high school students. This is probably apprehensive considering that in the curriculum of 1994 junior high school students are expected to master 15,000 entries. This fact is possible about our national (INAP) and international literacy achievements (PISA and PIRLS). This indicates that the book Indonesian junior high school students need to pay more attention and develop (add) the use of vocabulary to read and develop it.

\section{B. Favourite Entry}

Favourite entry marked with frequent use the entry is in the student's book. Table 3 will show the details of the top ten favourite words/entries per class.

TABLE 3. THE TEN FAVOURITES ENTRY

\begin{tabular}{|c|c|c|c|c|c|c|}
\hline \multicolumn{2}{|c|}{ Kelas VII } & \multicolumn{2}{|c|}{ Kelas VIII } & \multicolumn{2}{|c|}{ Kelas IX } & \\
\hline Entry & $\begin{array}{l}\text { Numb } \\
\text { er }\end{array}$ & Entry & $\begin{array}{l}\text { Num } \\
\text { ber }\end{array}$ & Entry & $\begin{array}{c}\text { Numb } \\
\text { er }\end{array}$ & \\
\hline yang & 1794 & yang & 99 & yang & 1417 & 5.010 \\
\hline dan & 1314 & dan & 1334 & dan & 1034 & 3.682 \\
\hline teks & 843 & di & 943 & teks & 1019 & $\begin{array}{l}\text { Teks }= \\
2.776\end{array}$ \\
\hline di & 783 & teks & 914 & kamu & 658 & $\begin{array}{c}\mathrm{Di}= \\
2.242\end{array}$ \\
\hline kamu & 683 & kamu & 683 & dengan & 599 & $\begin{array}{c}\text { Kamu } \\
= \\
1.965\end{array}$ \\
\hline $\begin{array}{c}\text { denga } \\
n\end{array}$ & 636 & $\begin{array}{c}\text { denga } \\
\mathrm{n}\end{array}$ & 645 & Di & 516 & $\begin{array}{c}\text { Denga } \\
\mathrm{n}= \\
1.880\end{array}$ \\
\hline itu & 540 & itu & 540 & itu & 515 & 1.595 \\
\hline pada & 523 & pada & 524 & dalam & 490 & $\begin{array}{l}\text { Dalam } \\
=1.482\end{array}$ \\
\hline dalam & 496 & dari & 513 & dapat & 424 & \\
\hline untuk & 475 & dalam & 496 & untuk & 403 & \\
\hline
\end{tabular}

The table 3 informs that there are eight of the same entries that occupy the position (sorted from the least favourites), namely: yang (5.010), dan (3.682), teks (2,776), di (2,242), kamu (1965), dengan (1880), itu $(1,595)$, di dalam $(1,482)$. The eight favourite entries are mostly clothing. Only one word is a noun, the word "teks" (the vocabulary of the Indonesian sciences).

\section{TABLE 4. FAVORITE RV IN THE BAHASA INDONESIA BOOK}

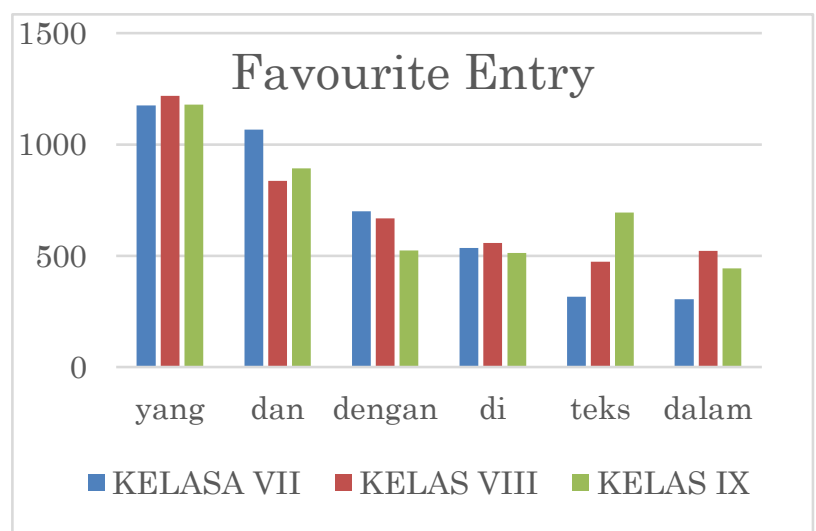

\section{Prefix}

The development of prefix and favourite prefix can be seen in the following table.

TABLE 5. PREFIX IN STUDENT BOOK OF SMP

\begin{tabular}{|l|l|l|l|l|}
\hline AFIKS & VII & VII & IX & Number \\
\hline me-/meN- & 3501 & 3875 & 2626 & 10002 \\
\hline pe-/peN- & 1351 & 1317 & 1441 & 4109 \\
\hline ber- & 1278 & 1250 & 976 & 3504 \\
\hline ke- & 1116 & 1082 & 1035 & 3233 \\
\hline di- & 1102 & 1101 & 1043 & 3246 \\
\hline se- & 1132 & 1117 & 821 & 3070 \\
\hline ter- & 767 & 767 & 765 & 2299 \\
\hline per- & 271 & 246 & 222 & 739 \\
\hline
\end{tabular}

In the table 5 it appears that the prefix "me-/meN-" is a favourite prefix for all classes. This means that an active form verb is a favourite form. Additionally, the prefix "pe-/peN-" in the second place. Next, the prefix "ber-" is also a favourite prefix in two classes.

\section{Infix}

Overall there is 46 infixes divided into class VII as much as 33 inserts, class VIII there is ten infix, and class IX there is three infixes. Apparently, only a few infixes exist in each class with favourite inserts "-el-" (class VII there are 29 and class VIII there are 7). The following sequence is" -em-" (VII: 4, VIII: 1; IX: 2), "-er-" (there is one in each class), "-in-" (only 1 in class VII). Most infixes exists in class VII and decrease during class VIII, decreasing again during class IX. In addition, in decapitations in KBBI (2016), the infixes is not treated as affixes because the beheading is performed between the infixes. Even the current inserted word is a basic word without any affixation (e.g. "te.lun.juk").

\section{E. Suffix}

The development of the suffixes contained in the book can be labelled as follows.

TABLE 6. THE SUFFIX IN THE STUDENT BOOK OF JUNIOR HIGH SCHOOL

\begin{tabular}{|c|r|r|r|r|}
\hline -an & 2947 & 2879 & 3203 & 9029 \\
\hline -kan & 2022 & 2007 & 1750 & 5779 \\
\hline -i & 582 & 570 & 557 & 1709 \\
\hline -nya & 406 & 407 & 266 & 1079 \\
\hline
\end{tabular}

Table 6 shows that the favourite suffixes that exist in all classes are the suffix "-an" on the first and "-kan" on the second. The suffixes function as a noun former (-an) seems to be a counterweight of the prefix "me-/meN-" and "ber-" as the verb former. 


\section{CONCLUSION}

Based on the results of the analysis that has been done can be summed up things as follows. First, Reading Vocabulary of the Junior High school students and the development of reading vocabulary are not so good because it decreases. Compared with the results of similar research in other countries, the book of Indonesian students with some slightly less dilemma supporting the development of literacy including the ability to think, create, and innovate junior high school students. Secondly, entry of most favourite is the clothing word. In addition to favourites with the highest number of occurrences of entries, there are also entries that only appear once. Thirdly, the first-order favourite prefix, i.e., meN- which functions in the form of a verb has been matched by the first-order favourite endings in all classes, namely "-an" which functions as a noun former. Infix ia not productive use.

\section{ACKNOWLEDGEMENT}

Authors wishing to acknowledge assistance from Research and Community Service Unit of Universitas Negeri Surabaya and financial support from The Ministry of Research, Technology and Higher Education of Republic of Indonesia.

\section{REFERENCES}

[1] D. Zuchdi, $K B$ Bahasa Indonesia untuk Sekolah Dasar di Indonesia Yogyakarta: FBS IKIP Yogyakarta, 1997.

[2] M. Mixan, "In-Dept Study of Vocabulary Development," Journal of Reading Improvement, vol. 50, no. 3, pp.118-120, 2015.

[3] D. Carrol, and Richman, The American Herritage Word Frequency Book, 1971. Retrived on February 12. 2016 from http://en.wikipedia.org/wiki/Word_lists_by_frequency

[4] D. August, M. Carlo, C. Dressler, and C. Snow, "The Critical Role of Vocabulary Development for English Language Learner,' Journal of Learning Disabilities Research and Practice, vol. 20, no. 1, pp 50-57, 2005.

[5] H. Kridalaksana, Kamus Linguistik. Jakarta: Gramedia, 2008.

[6] R. Lado, Language Teaching : A Scientific Approach, New York: McGraw-Hill, 1964.

[7] E. Dale, Vocabulary measurement: Techniques and major findings. Elementary English, vol.42, pp. 895-901, 1965.

[8] Sarwadi, et all, Penelitian Penguasaan Kosakata Bahasa Indonesia Murid Kelas 6 Sekolah Dasar di Jawa Tengah dan Daerah Istimewa Yogyakarta. Yogyakarta: Proyek Penelitian Bahasa dan Sastra Indonesia dan Daerah, 1978.

[9] Depdikbud, Kurikulum Bahasa Indonesia. Jakarta, 1995.

[10] Depdikbud, Kurikulum Berbasis Kompetensi. Jakarta, 2000.

[11] D. Supriadi,.Anatomi Buku Sekolah di Indonesia. Yogyakarta: Adi Cita, 2000

[12] Sudaryanto, Metode Penelitian Linguistik. Yogyakarta, 2010. 